\title{
Analysis of Public Satisfaction Index on the Regional Library Service at the Autonomous Regency
}

\author{
Hardiyansyah $^{1 *}$, R. Junita 2 , D. Triana ${ }^{3}$, Koesharijadi ${ }^{1}$, D. Mellita ${ }^{1}$, M. Akbar ${ }^{1}$ \\ ${ }^{1}$ Universitas Bina Darma, Palembang, Indonesia \\ 2Universitas Tamansiswa, Palembang, Indonesia \\ ${ }^{3}$ Civil servants at Ogan KomeringIlir Local Library \\ *hardiyansyah@binadarma.ac.id
}

\begin{abstract}
This study aims at finding out the community satisfaction index on the service of the Regional Library of Ogan KomeringIlir (OKI) regency. Through a quantitative descriptive method with questionnaire distribution to 150 respondents, the result showed that the public service has run well. As all components of the community satisfaction index were in "good" category with an average score of 77.61. The component of service that received the highest score was "courtesy and friendliness" of the serving personnel with a score of 3.22. Meanwhile, "terms of service" component got the lowest score 3.02. In other words, things related to various requirements in obtaining the service should be of particular concern because this component obtained the lowest score. There should be a solution to this problem so the community would be able to access the service easily without any complaints or dissatisfaction.
\end{abstract}

Keywords: Public Satisfaction Index, public services, service quality, library, literacy, OKI

\section{Introduction}

The Ministry of Education and Culture of the Republic of Indonesia encourages all education stakeholders to further develop literacy (reading and writing) in schools, families, and communities. The "Literacy Movement" which was launched by the Ministry of Education and Culture in 2015 could serve as a means to improve collaborations among education stakeholders. To support the movement, the infrastructures need to be set up, such as reading facilities i.e. libraries with provided books, either by the community orby the local government. One of the autonomous regencies in South Sumatra Province that has developed its reading facilities is Ogan KomeringIlir (OKI). The regional Library of OKI has widely served its function as a public community center. Throughout the time and with the development of science and technology, the library has added more collections which fall into various types, numbers, shapes, and quality. The collections are either in printed form or in a particular form. In the era of globalization and information technology, the information transfer is very fast. Any information can flow profusely from all over the world. Therefore, the Regional Library $\mathrm{OKI}$ as a center of information selects, collects, processes, presents and empowers resources as well as possible, and strive to provide a high quality service i.e. a service which is complete, fast, timely, simple, cheap, fair, simple, and with no discrimination.

As there are more people coming to the library, there has been a need to evaluate the library quality of service which really depends on the perception of the community who receives the service. Satisfaction is the reaction or responses of consumers regarding need fulfillment. Satisfaction is the assessment of the characteristics or features of any particular products or services or information of the product, which provides consumers the level of excitement associated with the fulfillment of consumers' need of consumption. Consumer satisfaction can be created through the quality of service and value (Zeithaml \& Bitner, 2003). During a period of three years, from 2013 to 2015, the number of visitors OKI Regional Library has increased (see Table 1.)

Table 1: The Growing Number of Visitors of OKI Regional Library 2013-2015

\begin{tabular}{lcl}
\hline No & Fiscal Year & Number of Visitors \\
\hline 1 & 2013 & 3076 visitors \\
2 & 2014 & 3360 visitors \\
3 & 2015 & 4055 visitors \\
\hline
\end{tabular}

Source: OKI Regional Library (2016)

Any levels of government (provincial, district or city government) are responsible of providing public libraries, as mandated in Article 7, section 1 and 2 of Government Regulation No. 38 of 2007 on the Division 
of Government Affairs among the Central Government, Provincial Government and District/City Government (RI, 2007). Thus, the implementation of this mandatory affair must be given serious attention and well managed as this has been a basic public service. There is no excuse for not paying attention to this. However, the implementation should be in proportion to the amount of available resources i.e. funds, human resources and other facilities and infrastructures. One of the ways to evaluate the performance of OKI regional library is by determining the level of community satisfaction. In this regard, this research focuses on the community satisfaction index the service of OKI Regional Library.

\section{Literature Review}

Since the policy of regional autonomy was implemented in 1999, public service quality has become one of the parameters of success of regional autonomy. Therefore, public services become the great theme of political campaigns of heads of local government candidates (governors, regents or mayors). For example, free public services for health care, schools, ID card and birth certificate issuing, and for the improvement of infrastructures (roads, bridges, etc.), with an expectation that people would vote. State that the new public management (NPS) has championed a vision of public managers as the entrepreneurs of a new, leaner, and increasingly privatized government, emulating not only the practices but also the values of business. Proponents of the new public management (NPM) have developed their arguments largely through contrasts with the old public administration. In this comparison, the new public management will, of course, always win. They argue here that the better contrast is with what they call the "New Public Service," a movement built on work in democratic citizenship, community and civil society, and organizational humanism and discourse theory. We suggest seven principles of the New Public Service, most notably that the primary role of the public servant is to help citizens articulate and meet their shared interests rather than to attempt to control or steer society (Denhardt \& Denhardt, 2007).

Argues that NPS as the latest paradigm of public administration puts public services as the primary activity of the administrators in in a country/region. One of the very essences of the NPS principle is how public administrators articulate and apportion the interests of citizens. The theoretical basis and epistemological foundation of NPS are the democratic theory. This theory states that the equality and individual freedom are allowed; the concept of public interest is a result of the dialogue of various values; the responsiveness of the public bureaucracy is addressed to citizens instead of clients, constituents or customers; the role of government is serving, accountability is a multi-faceted concept: whereby law, values, community, political norm, professional standard must be attended. Organizational structure is a collaborative structure with an ownership which is shared internally and externally. Assumptions that affect the motivation of employees and administrators are public services with an appeal to serve the community (Hardiyansyah, 2015). Government has been increasingly paying serious attention to public services since the enactment of Law No. 25 of 2009 on Public Service (Parasuraman et al., 1985). Although this law does not fully adopt the paradigm of NPS, this at least has made an effort to treat citizens as citizens, not as customers or clients, and it is oriented to the interests of public service and improving the quality of public services.

State that there are seven basic requirements of the service quality, namely: (1) Reliability which includes setting the facilities, implementing adherence-based systems and procedures, increasing the effectiveness of work schedules and increasing the coordination among departments; (2) Responsiveness which includes speeding up services, training the employees, simplifying the systems and procedures, integrating services, simplifying the bureaucracy and reducing the centralization of decision; (3) Competence which includes improving the professionalism of the employees and improving the quality of administration; (4) Credibility which includes improving the mental attitude of the employees to work hard, improving employee's honesty and eliminating collusion; (5) Tangibles which includes the expansion of capacity, the arrangement of facilities, infrastructure improvement, equipment procurement, communication facility improvement. and infrastructure improvement; (6) Understanding the customers which include systems and procedures that respect consumers / customers as well as supports to consumers/ customers; (7) Communication which includes clarifying the responsible party in any activity, improving the effectiveness of communication with clients and creating an integrated information management system (Fitzsimmons \& Fitzsimmons, 2001). 
State that a quality service can improve the satisfaction of both the community and customers. If people are not satisfied with a service that is provided, that service can be regarded as a not qualified or inefficient service. Therefore, the quality of service is very important and has always focused on customer satisfaction. Customer satisfaction is the customers' perception that a supplier has met or exceeded their expectation (Kotler, 1997; Tjiptono, 2004; Sukasah, 2004; Renwarin, 2005; Chinomona et al., 2013; Is'haq et al., 2013; Keshavarz \& Ali, 2015). The categories of customer satisfaction are less satisfied, satisfied and very satisfied. The measurement of quality of service and customer satisfaction, can be used for several purposes, namely:

- To study each customer's perceptions on the quality of service which is demanded, preferred and accepted or not accepted, which eventually the customers are satisfied and keep the cooperation;

- To find out the needs, requirements and expectations of customers in the present time and in the future towards the service which is provided by the company with an expectation that the customers will be satisfied;

- To improve the quality of services in accordance with customer expectations; and

- To develop a work plan and enhance the service quality in the future.

\section{Methodology}

The method used in this research is a quantitative method with descriptive analysis through survey techniques. The populations in this study were visitors of OKI Regional Library. Samples were drawn through accidental sampling, in which respondents were taken as samples incidentally when the observation was ongoing. Samples taken in this study were 150 respondents with a consideration that the samples were representative enough to represent the population. The data were collected by means of questionnaires (referring to the Decree of the Minister of State for Administrative Reform: KEP/25/M.PAN/2/2004) (RI, 2004) using frequency tables. Next, after the questionnaires were collected, data processing and tabulation were then performed. The value of community satisfaction index (CSI) was calculated using the "weighted average score" of each service component. In calculating the index of people's satisfaction, 14 service components were studied, each had the same weight. To obtain the value of CSI service unit, the researcher had to first obtain the weighted average score with the following formula:

$$
\text { Weighted average score }=\frac{\text { Total score }}{\text { Number of components }}=\frac{1}{4}=0 / 071
$$

To obtain the value of CSI, the researcher used the following formula:

\section{CSI $=\underline{\text { The total amount of perception score of each component } X \text { weighted score }}$}

$$
\text { The number of filled components }
$$

For easy interpretation of the CSI score, which range between the score of 25-100, the results of the calculation were converted to the value with a base of 25, with the following formula: (CSI x 25). The score of perception, CSI interval, converted CSI interval, quality of service and the performance of the service unit are as follows:

Table 2: The score of perception, CSI interval, converted CSI interval, quality of service and the performance of the service unit

\begin{tabular}{cccll}
\hline Perception Score & CSI interval & Converted CSI interval & $\begin{array}{c}\text { Quality of } \\
\text { Service }\end{array}$ & $\begin{array}{c}\text { Performance of } \\
\text { service units }\end{array}$ \\
\hline 1 & $1,00-1,75$ & $25-43,75$ & $\mathrm{D}$ & Poor \\
2 & $1,76-2,50$ & $43,76-62,50$ & $\mathrm{C}$ & Fair \\
3 & $2,51-3,25$ & $62,52-81,25$ & B & Good \\
4 & $3,26-4,00$ & $81,26-100$ & A & Very Good \\
\hline
\end{tabular}

Source: KEP/25/M.PAN/2/2004 (RI, 2004).

The questionnaire data from each respondent were entered into a form consisting of service components i.e. component 1 (C1) up to component 14 (C14). The next step was to get the average value of each service component. It is as follows: the score of each service component was summed (downward) in accordance 
with the number of questionnaires filled out by the respondent, and then to get the average score of each service component, the total number of each component of service was divided by the number of people who responded. To obtain a weighted average of each service component, the total average score of each service component was multiplied by 0,071 as the weighted average score. The score of service index was obtained by summing the weighted average score of the 14 components. The questionnaire data were compiled and arranged according to different profile of the respondents i.e. age, gender, education and profession. This information can be used to determine the profile of respondents and the tendency of the answers given for the objectivity of the analysis.

\section{Results and Discussions}

From 150 respondents, the researcher obtained the following results. In terms of their age, the respondents were grouped into 4 different groups. It can be seen in the following table

Table3: Respondents in terms of their age

\begin{tabular}{lrr}
\hline Age & Frequency & Percentage \\
\hline $10-20$ & 58 & 38,67 \\
$21-30$ & 69 & 46 \\
$31-40$ & 17 & 11,33 \\
$41-50$ & 6 & 4 \\
Total & 150 & 100 \\
\hline
\end{tabular}

Source: Primary data

Table3shows that the respondents who are between 21 and 30 years old dominate the whole number of respondents i.e. $46 \%$. Meanwhile, $38,67 \%$ of the total number of 31 and 40 years old were $11,33 \%$ of the total number of the respondents. The rest are the respondents who are between 41 and 50 years old i.e. $4 \%$ of the total number of the respondents. In terms of gender, most of the respondents were women $76 \%$ of the total number of respondents, while men are only $24 \%$ of the total number of respondents. Of education level, $50,67 \%$ of respondents were senior high school graduates dan $24 \%$ of respondents were bachelor degree graduates. Next, $14,67 \%$ of respondents were elementary school students and 6,67\% respondents were junior high school students. The rest i.e. 3,33\% of respondents were one /three-year college graduates and $0,66 \%$ of respondents were master's degree graduates. Most of the respondents were university students i.e. $64,67 \%$ of the total number of students, civil servants/soldiers/police officers were $10,67 \%$, employees were $7,33 \%$ of the total number of respondents, $2 \%$ of respondents were self-employed. The rest were respondents who did not belong to the five categories mentioned. They were $15,33 \%$ of the total number of respondents. In this research, the respondents were also grouped in terms of their gender. The distribution can be seen in the following table.

Table4: Respondents in terms of their gender

\begin{tabular}{lrc}
\hline Gender & Frequency & Percentage \\
\hline Men & 36 & 24 \\
Women & 114 & 76 \\
Total & 150 & 100 \\
\hline
\end{tabular}

Source: Primary data

Table 4 shows that $76 \%$ of respondents were women and $24 \%$ of respondents were men. The difference is quite big i.e. 3: 1 . The education level of the respondents was categorized into five classes, as it can be seen in the following table. 
Table 5: Respondents in terms of their education level

\begin{tabular}{lrr}
\hline Education & Frequency & Percentage \\
\hline Elementary school & 22 & 14,67 \\
Junior High School & 10 & 6,67 \\
Senior High School & 76 & 50,67 \\
One/Three years' college & 5 & 3,33 \\
Undergraduate/bachelor's degree & 36 & 24 \\
Master's degree & 1 & 0,66 \\
Total & 150 & 100 \\
\hline
\end{tabular}

Source: Primary data

Table 5 shows that there were $50.67 \%$ of respondents were senior high school graduates who were studying at universities and $24 \%$ of respondents were bachelor's degree graduates, 14,67\% were elementary school students and $6.67 \%$ were junior high school students. The rest, 3, 33\%, were one /three -year college educated and $0.66 \%$ were master's degree educated. In terms of their professions, the respondents were grouped into 6 categories. They are as follow:

Table 6: Respondents based on their professions

\begin{tabular}{lrr}
\hline Professions & Frequency & Percentage \\
\hline Civil servants/ soldiers/police officers & 16 & 10,67 \\
Employees & 11 & 7,33 \\
Self-employed & 3 & 2 \\
Students/University students & 97 & 64,67 \\
Others & 23 & 15,33 \\
Total & 150 & 100 \\
\hline
\end{tabular}

Source: Primary data

Table 6 shows that $64,67 \%$ of respondents were university students, $10,67 \%$ of respondents were civil servants/ soldiers/police officers, $7,33 \%$ were employees, $2 \%$ were self-employed, and the rest, $15,33 \%$, were not in the five categories mentioned. This Community satisfaction index was based on the 14 components which are stated in the Decree of the State Minister of Administrative Reform No. KEP /25/M.PAN/2/2004 on general guidelines for community satisfaction index preparation in government agencies. The measurement of community satisfaction index has 14 indicators. The data were tabulated in each indicator to get the frequency and percentage of each unit. The tabulation and frequency are as follows:

Service procedure: This component covers the ease of the service stages provided to the community in terms of the simplicity of the service flow. This is related to all stages of the procedure or service provided to the visitors. The results showed that $76 \%$ of respondents stated that the service procedure was very easy. $15.33 \%$ of respondents said it was easy. $4.67 \%$ of respondents expressed that it was less easy, and $4 \%$ said it was not easy.

Terms of service: These are the technical and administrative requirements necessary to obtain the services in accordance with the type of service. The results showed that $82.67 \%$ said the service requirements are in accordance with the requirements. A total of $10.66 \%$ of respondents stated it was very appropriate. The remaining $4.67 \%$ of respondents expressed it was less suitable and $2 \%$ of the respondents it was not appropriate.

Clarity: This includes the presence and assurance of the librarians in providing services to visitors (name, position, authority and responsibility). The results showed that $71.33 \%$ of respondents stated that in terms of clarity, the librarians are clear and as much as $21.34 \%$ of respondents stated they were very clear. The remaining $5.33 \%$ of respondents expressed that they were less clear and as much as $2 \%$ of respondents said they were unclear.

Discipline: It includes the seriousness and certainty of librarians who provide services regarding the consistency of working time according to applicable regulations. The librarians' discipline can be seen from 
the statement of respondents in which $72.67 \%$ of respondents stated that the librarians were disciplined and $19.33 \%$ of respondents stated they were much disciplined. The remaining $7.33 \%$ of respondents expressed that they were lack of discipline, while as much as $0.67 \%$ of respondents said the librarians were not discipline.

Responsibility: This is the clarity of authority and responsibility of the librarians in terms of service administration and fulfillment. $76 \%$ of respondents said that the librarians were responsible and $20.67 \%$ of respondents stated the librarians were very responsibility. The remaining $3.33 \%$ of respondents said that the librarians were less responsible.

Capability: This is the ability of the service personnel, the level of expertise and skills of librarians in giving / finishing services to the public. A total of $76.67 \%$ of respondents stated that the librarians were capable in giving services. The remaining $21.33 \%$ of the respondents were very capable. $2 \%$ of respondents said that the respondents were less capable.

Speed of service: This is the target of the service time in which the service can be completed within the time specified by the library as the provider of service. $75.33 \%$ of respondents stated that the speed of the service was quick. The remaining $14 \%$ of respondents stated it was very quick, Then, $10.67 \%$ of respondents said that it was less quick.

Service Fairness: It means that the service is delivered fairly to the community by neglecting their social statuses. A total of $76.67 \%$ of respondents said that the services were fairly performed have been fair. A small part of the remaining i.e. $20 \%$ of respondents stated it was very fair and as much as $2.67 \%$ of respondents said it was not really fair and $0.66 \%$ of respondents said that it was not fair.

Courtesy and friendliness: These are the attitudes and behavior of the librarians in providing services to the community. Being polite and friendly as well as appreciative are the expectations of the visitors. $68 \%$ of respondents said that the librarians were polite and friendly. The remaining $27.33 \%$ of respondents stated the librarians were very polite and friendly. $4 \%$ of respondents expressed that the librarians were less polite and friendly and $0.67 \%$ of respondents said that the librarians were not polite and friendly.

The rationality of the service charge: This includes the community on the cost specified in the service process. $71.33 \%$ of respondents said that the service charge was reasonable. $22 \%$ of respondents stated the service charge was very reasonable and $6 \%$ of respondents stated that the service charge was less reasonable. The, $0.67 \%$ of respondents stated that the service charge was not reasonable.

Service Charge Certainty: This means that the cost that has been set up matches with the service fees charged to visitors. $52 \%$ of respondents stated that it matched, and $26.67 \%$ of respondents said it always matched, and $18.66 \%$ of respondents said sometimes it matched and $2 \%$ of the respondents stated it did not match.

Service schedule certainty: This has something to do with when the service starts and ends or the opening and the closing time of the library. A total of $49.33 \%$ of respondents said the schedule was on time, $34 \%$ of respondents stated that the schedule was always on time, $16 \%$ of respondents stated sometimes the schedule was on time and $0.67 \%$ of the respondents stated that the library schedule was not on time.

Environmental comfort: This is the condition of service facilities and infrastructure which were clean, neat and organized so that they can provide a sense of comfort to the visitors of the library. A total of $74.67 \%$ of respondents rated that the library had a comfortable environment. A total of $18.66 \%$ of respondents stated it was very comfortable. $4.67 \%$ of respondents stated that it was less comfortable and the remaining $2 \%$ of respondents stated that it was not comfortable.

Security: This ensures the security level of the library environment. $74 \%$ of respondents said that the library was secure, as much as $22.67 \%$ of respondents stated it was very secure, and the remaining $3.33 \%$ of respondents expressed that it was less secure. After calculating, the researcher presented the results. The 
results were in the form of Community Satisfaction Index (HPI) on OKI Regional Library service. The followings are the weighted average scores of each service component: $\mathrm{C} 1=453 ; \mathrm{C} 2=453 ; \mathrm{C} 3=467 ; \mathrm{C} 4$ $=466 ; \mathrm{C} 5=476$; $\mathrm{C} 6=479 ; \mathrm{C} 7=455 ; \mathrm{C} 8=474 ; \mathrm{C} 9=483 ; \mathrm{C} 10=472 ; \mathrm{C} 11=462 ; \mathrm{C} 12=475 ; \mathrm{C} 13=465 ; \mathrm{C} 14=$ 479.

Table 7: Weighted Average Score of each service component

\begin{tabular}{llcl}
\hline No & Service Component & Score & Remark \\
\hline 1 & Service Procedure & 3,020 & Good \\
2 & Terms of Service & 3,020 & Good \\
3 & Clarity & 3,113 & Good \\
4 & Discipline & 3,106 & Good \\
5 & Responsibility & 3,173 & Good \\
6 & Capability & 3,193 & Good \\
7 & Service Speed & 3,033 & Good \\
8 & Service Fairness & 3,160 & Good \\
9 & Courtesy and Friendliness & 3,220 & Good \\
10 & Rationality of Service Charge & 3,146 & Good \\
11 & Service Charge certainty & 3,080 & Good \\
12 & Service Schedule certainty & 3,166 & Good \\
13 & Environmental comfort & 3,100 & Good \\
14 & Security & 3,193 & Good \\
\hline
\end{tabular}

Source: data were processed from primary data

Average score of each service component

Average score of each component $=\underline{\text { The total amount of component score }}$

The number of questionnaire

WAS-C1 $=453 / 150=3,020$; WAS-C $2=453 / 150=3,020$; WAS-C $3=467 / 150=3,113$;

WAS-C4 $=466 / 150=3,106$; WAS-C $5=476 / 150=3,173$; WAS- $c 6=479 / 150=3,193$;

WAS-C7 $=455 / 150=3,033$; WAS-C8 $=474 / 150=3,160$; WAS-U9=483 $/ 150=3,220$;

WAS-C10 $=472 / 150=3,146$; WAS-C11 $=462 / 150=3,080$;

WAS-C12 $=475 / 150=3,166$; WAS-C $13=465 / 150=3,100$;

WAS-C14 $=479 / 150=3,193$

\section{Weighted average score $($ WAS $)=$ WAS of each component $\mathrm{x} 0,071$}

$\mathrm{C} 1=3,020 \times 0,071=0,214 ; \mathrm{C} 2=3,020 \times 0,071=0,214 ; \mathrm{C} 3=3,113 \times 0,071=0,221$;

$\mathrm{C}=3,106 \times 0,071=0,220 ; \mathrm{C} 5=3,173 \times 0,071=0,225$; $\mathrm{C} 6=3,193 \times 0,071=0,226$;

$\mathrm{C} 7=3,033 \times 0,071=0,215 ; \mathrm{C} 8=3,160 \times 0,071=0,224 ; \mathrm{C} 9=3,220 \times 0,071=0,228$;

$\mathrm{C} 10=3,146 \times 0,071=0,223 ; \mathrm{C} 11=3,080 \times 0,071=0,218 ; \mathrm{C} 12=3,166 \times 0,071=0,224$

$\mathrm{C} 13=3,100 \times 0,071=0,220 ; \mathrm{C} 14=3,193 \times 0,071=0,226$

WAS $=3,104593$

The service index value is 3.104593 services. If the value is converted using the base of 25 then the result is 77.61483. Based on these calculations it can be said that the quality of service is "B". This means that the service performance of OKI Regional Library is good. As explained in the previous section, the quality of service is an activity that emphasizes the satisfaction of service recipients, which is implemented on the activities that produce the best service and the ability to adapt appropriately with the changing needs of the service recipients. The approach focuses on the organization goal to serve the needs of service recipients, by providing services that have the possible highest quality and have a long-term commitment to make changes continuously.

Based on the results of the study, $46 \%$ of the respondents were in the age group of 21-3 years old. Most of the respondents were university students i.e. $64.67 \%$ of the total respondents. Female respondents were $76 \%$ of the total respondents. Then, $50.67 \%$ of respondents were senior high school educated. This means the most dominant respondents were females. Most respondents considered that the service procedure was very easy. 
This means that people felt a lot of convenience with the service procedures. The circulation process services include borrowing and returning books. The fact was that this service procedure was very easy. All systems have been computerized using INLIS application (Integrated Library System Information). This includes the visitor data collection, membership card printing, and book borrowing and returning data. The visitors got the service in accordance with the type of service, and with the terms of service. The service given was in accordance with the existing regulations. However, the regulation of the library which requires ID card for membership registration gave problems to elementary school students who wanted to become members of the library. This was because most of them did not have ID cards yet. The librarians were very clear in giving explanation and in giving services. In relation to this, there was a special schedule of which librarians that were in charge, the visitors did not have to wait since there would always be librarians on duty.

The librarians were discipline in terms of regulations and working hours. Most visitors rated that the service officers/librarians were disciplined. There was a schedule of which librarians who were in and who were out. In performing their duties, the librarians were responsible, had a good clarity toward their authority and responsibility on the service administration and fulfillment. This was reflected by the fact that the librarians were always ready to assist in the service desk. They were serious on their duty and they did not chat among them during work. The librarians had performed the ability to do a service to the community i.e. the level of expertise and skill of the librarians in giving services. For example, is the ability of librarians in terms of providing information to visitors about the location of the book and the author's name. In the meantime, the circulation services already use the INLIS application. Regarding this, all librarians have got training in operating the program, making it easier for them to provide services to the visitors. The librarians gave a quick service. The speed of service is the timeliness of service and openness of the completion time of service. This includes technical and administrative services. These two services must be balanced and integrated. Many visitors rated the service process was fast. Long queues in borrowing and returning books and in registering for a membership were not visible during the observation as the officers in charge were skillful. However, sometimes because of technical problems, the membership card-making service which ideally can be done less than an hour could not be completed within the same day as there was a problem with the printer. The librarians were fair and not discriminative. This was evident from the attitudes of the librarians when serving. Every visitor would have to queue based on their arrival. The librarian was also polite and friendly as rated by the visitors. Ideally, they are supposed to smile when serving and apologize when making mistakes and for not giving a satisfactory service. The service charge was also considered reasonable by visitors especially since most of the visitors were students. The membership card is free of charge. However, the members will be fined when they return the books late. The price the members had to pay was reasonable i.e. Rp. 500 per day. The service charge should be adjusted with the market price. For example, the library did not provide photocopying service. If the members wanted to copy, they had to go out of the library. This kind of service could have been given by the library with a reasonable service charge.

The opening and closing hours of the library were on schedule. There was a special schedule of which librarians in charge. The service facilities and infrastructures were clean, neat and organized so that it could provide a sense of comfort to the visitors of the library. The reading room was comfortable. The facilities available in the room were also quite adequate. The rooms had air-conditioners and rugs. When there was a noise or cellphone sound, the librarians will quickly caution the visitors. The library was secure. The security services included a parking lot and the deposit box. Although there was no special parking attendant, the library environment i.e. the parking lot was safe. There were officers in the deposit counter. Therefore, the visitors felt secure when they had to leave their luggage (handbags, wallets, jackets, etc.)

\section{Conclusion}

From the results of research and discussion, the researcher concluded that the public service performed by the government has been running well. This was supported by the CSI of 77.61 which means that the community service is in a good category. The service component that received the highest score was the component of courtesy and friendliness of the librarians with a score of 3.22. meanwhile, the terms of service component got the lowest score i.e. 3.02. However, things related to various requirements in obtaining the service should be of particular concern because this component obtained the lowest score. There should be a 


\section{Journal of Social and Development Sciences (ISSN 2221-1152)}

Vol. 8, No. 4, pp. 24-32, December 2017

solution to this problem so the community would be able to access the service easily without any complaints or dissatisfaction.

Acknowledgement: The support of authors by Research institutions and community service (LPPM) Universitas Bina Darma, Palembang, Indonesia.

\section{References}

Chinomona, R., Mofokeng T. \& Poee, D. (2013). The Influence of Condition of Minibus Taxis, Compliance with Road Rules on Quality of Service and Commuter Satisfaction in Harrismith, South Africa. Mediterranean Journal of Social Sciences, 4(14), 319-328.

Denhardt, J. V. \& Denhardt, R.B.(2007). The New Public Service: Serving, not Steering. Expanded Edition. Armon, New York: M.E. Sharpe.

Fitzsimmons, J. A. \& Fitzsimmons M. J. (2001). Service Management: Operations, Strategy, and Information Technology. Third Edition. Singapore: McGraw-Hill Book Co.

Hardiyansyah. (2015). Communication Public Services. Yogyakarta: Gava Media.

Is'haq, M.M., Musa, S. I.\& Bello, T.H. (2013). Quality of Property Management Service in Public Educational Buildings in Nigeria. Mediterranean Journal of Social Sciences, 4(2), 753-759.

Keshavarz, Y. \& Ali, M.H. (2015). The Service Quality Evaluation on Tourist Loyalty in Malaysian Hotels by the Mediating Role of Tourist Satisfaction. Mediterranean Journal of Social Sciences, 6(3), 680-686.

Kotler, P. (1997). Marketing management: Analysis, planning, implementation, and control. Upper Saddle River, NJ: Prentice Hall.

Parasuraman, A., Zeithaml, V. A. \& Berry, L. L. (1985). A conceptual Model of Service Quality and its Implications for Future Research. Journal of Marketing, 4(49), 41-50.

Renwarin, A. A. (2005). Bureaucratic behavior influence on the quality of health services. Thesis. Bandung: PPs Unpad.

RI. (2004). Decree of the Minister of State for Administrative Reform: KEP/25/M.PAN/2/2004.

RI. (2007). Government Regulation No. 38 of 2007 on the Division of Government Affairs among the Central Government, Provincial Government and District/City Government.

Sukasah, T. (2004). Climate Influence Organizational Communication and Information Flow in the Public Service to the Public Satisfaction in Bekasi. Dissertation. Bandung: PPs Unpad.

Tjiptono, F. (2004). Management Services. Yogyakarta: Andi.

Zeithaml, V. A. \& Bitner, M. J. (2003). Service Marketing Int'l Edition. New York: McGraw Hill Inc. 